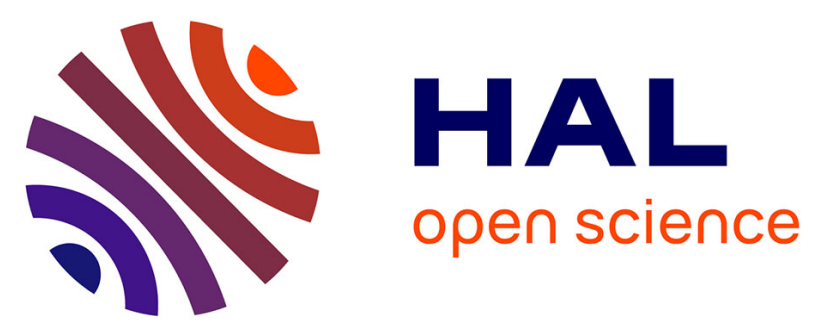

\title{
Writing tremor: Should we look for a TOR1A mutation
}

Cécile Aerts, Alain Destée, Luc Defebvre, Alexandre Kreisler, François

Cassim, Isabelle Strubi-Vuillaume, Bernard Sablonniere, Gwenaëlle

Collod-Béroud

\section{To cite this version:}

Cécile Aerts, Alain Destée, Luc Defebvre, Alexandre Kreisler, François Cassim, et al.. Writing tremor: Should we look for a TOR1A mutation. Journal of the Neurological Sciences, 2017, 382, pp.146 - 147. 10.1016/j.jns.2017.09.048 . hal-01670211

\section{HAL Id: hal-01670211 \\ https://hal.science/hal-01670211}

Submitted on 21 Dec 2017

HAL is a multi-disciplinary open access archive for the deposit and dissemination of scientific research documents, whether they are published or not. The documents may come from teaching and research institutions in France or abroad, or from public or private research centers.
L'archive ouverte pluridisciplinaire HAL, est destinée au dépôt et à la diffusion de documents scientifiques de niveau recherche, publiés ou non, émanant des établissements d'enseignement et de recherche français ou étrangers, des laboratoires publics ou privés. 
Letter to the Editor

Writing tremor: Should we look for a TOR1A mutation?

\section{A R T I C L E I N F O}

\section{Keywords:}

Writing tremor

TOR1A mutation

DYT1 dystonia

\section{Dear Editor,}

Three forms of dystonic tremor syndrome have been described [1]. Dystonic tremor corresponds to tremor observed in a body region affected by dystonia; it is usually a postural, kinetic, focal tremor, with an irregular amplitude and a variable frequency. Secondly, tremor associated with dystonia is present in a body region not affected by dystonia but is associated with dystonia in another body region. Lastly, dystonia gene-associated tremor corresponds to isolated tremor observed in patients with a mutation known to cause dystonia; dystonic posture is sometimes observed over the course of the disease. The latter entity is the most challenging to diagnose; for example, it can be difficult to differentiate from essential tremor [2]. Primary writing tremor is different in that no causal mutation was demonstrated in this disorder [3].

Here, we report on a family with two affected members (Fig. 1). The index case (II:3) presented with generalized dystonia from the age of 10 onwards. A TOR1A mutation (c.907delGAG) was identified. His brother (II:5) presented with mild, progressive writing difficulties from the age of 42 onwards (in 1990). After an initial consultation in 1999, writing tremor with jerky pronosupination developed over the next 13 years (Video 1 ). The wrist flexion seen on the video suggests dystonia, but a compensatory measure cannot be ruled out: the patient stated that his wrist was flexed in some conditions and extended in other conditions, in order to effectively control the tremor (Video 2). Apart from these features, the patient's clinical status was normal. Patient II:5 had the same TOR1A mutation as the index case. Various non-surgical treatments failed to relieve the patient's symptoms. The patient was lost to follow-up in 2013 but consulted again in September 2016. The clinical situation had changed dramatically; we observed marked dystonic flexion of the right wrist, associated with an irregular, postural, kinetic tremor of both hands (Video 3). Surprisingly, the patient's writing had not worsened. Polymyographic electromyography ruled out essential tremor and myoclonus.

It cannot be determined whether, at the onset of the disease, patient II:5 presented with dystonic tremor or isolated tremor (dystonia geneassociated tremor). Indeed, although dystonia gene-associated tremor is a classical concept, cases are very rare. Isolated head tremor (in the presence or the absence of dystonic posture of the neck) has been reported in families with an ANO3 mutation (DYT24) [4]. Upper limb tremor was described in a patient with an SGCE mutation [5]. In other publications, dystonia gene-associated tremor has not been clearly proven. For example, the patient described by Caceres-Redondo et al. (TOR1A mutation) [6] presented with a postural tremor of upper limb, but it is unclear whether it was strictly isolated at onset or associated to a dystonia. In Markova et al.'s [7] description of a family with TOR1A mutation, the member with isolated hand tremor lacked a molecular diagnosis. Erro et al. [8] described a family whose members suffered from primary writing tremor and dystonia - showing that tremor can indeed be an isolated feature of dystonia. However, no mutations were found (DYT1 was ruled out).

Furthermore, the clinical presentation of patient II:5 was remarkable for a DYT1 dystonia: late onset (42 years old, whereas DYT1 dystonia typically presents in childhood or adolescence); mild phenotype (a focal, task-specific dystonic tremor); and slow course (the patient's dystonic posture became worse more than 20 years after the onset) [9]. In view of the late onset, a linkage to chromosome 18p (DYT7) could have been considered [10]; patients with this defect can present with writer's cramp and tremor. To reduce the risk of late diagnosis, it is essential to record a detailed family history for patients with writing tremor. As soon as an impairment was observed in patient II.5, a history of dystonia in the sibship pointed us towards a diagnosis of dystonic tremor rather than another cause of writing tremor (such as primary writing tremor).

In summary, screening for mutations (especially a TOR1A mutation or a SGCE mutation) should be considered in patients with writing tremor when there is a family history of dystonia. However, it should be borne in mind that all forms of genetically determined dystonia may present with tremor of the hand. Lastly, in patients with dystonia gene-associated writing tremor, dystonia may occur after several decades.

Supplementary data to this article can be found online at https://doi.org/10.1016/j.jns.2017.09.048.

\section{Acknowledgment}

The authors wish to thank Dr. David Fraser (Biotech Communication, Damery, France) for editorial assistance. 


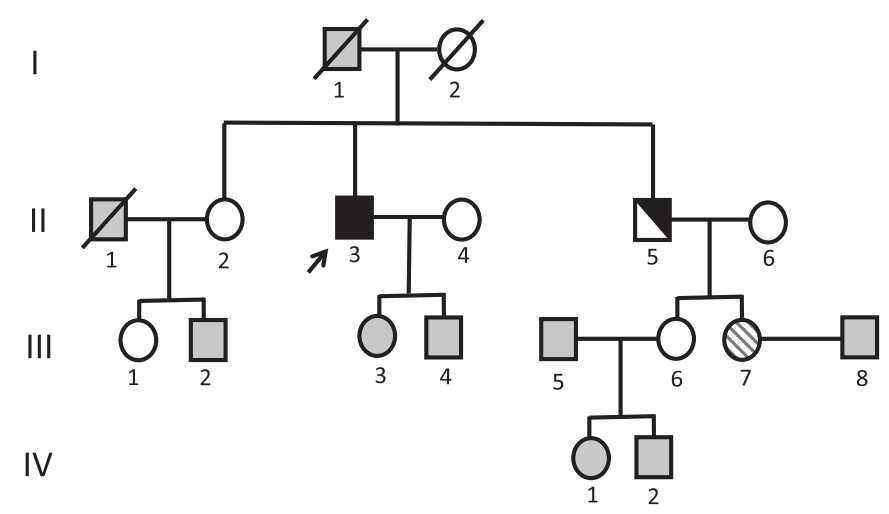

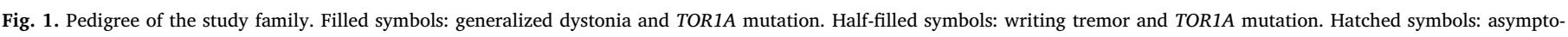
matic, with a TOR1A mutation. Grey symbols: asymptomatic, TOR1A status unknown. Unfilled symbols: asymptomatic, no TOR1A mutation. Arrow: proband.

\section{Funding}

No specific funding was received for this work.

\section{Disclosures}

The authors declare that there are no conflicts of interest relevant to this work. Dr. Kreisler reports personal fees from Allergan France SAS, grants and personal fees from Ipsen, personal fees from Merz Pharma France, outside the submitted work. Pr. Destée reports personal fees from Zambon France, outside the submitted work.

\section{References}

[1] G. Deuschl, P. Bain, M. Brin, Consensus statement of the movement disorder society on tremor. Ad hoc scientific committee, Mov. Disord. 13 (Suppl. 3) (1998) 2-23.

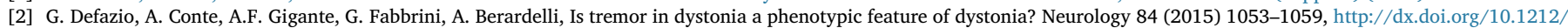
WNL.0000000000001341.

[3] C. Hai, W. Yu-ping, W. Hua, S. Ying, Advances in primary writing tremor, Parkinsonism Relat. Disord. 16 (2010) 561-565.

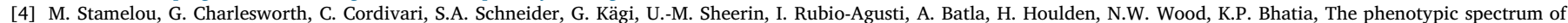
DYT24 due to ANO3 mutations, Mov. Disord. 29 (2014) 928-934, http://dx.doi.org/10.1002/mds.25802.

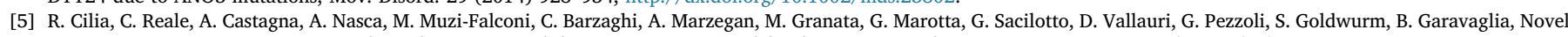
DYT11 gene mutation in patients without dopaminergic deficit (SWEDD) screened for dystonia, Neurology 83 (2014) 1155-1162, http://dx.doi.org/10.1212/WNL. 0000000000000821

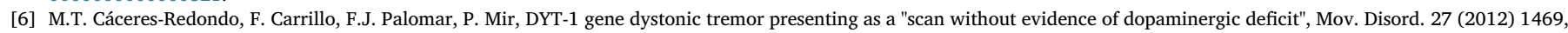
http://dx.doi.org/10.1002/mds.25171.

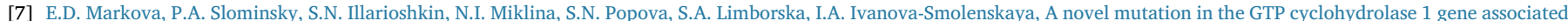
with a broad range of clinical presentations in a family with autosomal dominant dopa-responsive dystonia, Eur. J. Neurol. 6 (1999) $605-608$.

[8] R. Erro, M. Ciocca, S.T. Hirschbichler, J.C. Rothwell, K.P. Bhatia, Primary writing tremor is a dystonic trait: evidence from an instructive family, J. Neurol. Sci. 356 (2015) 210-211, http://dx.doi.org/10.1016/j.jns.2015.06.040.

[9] L. Ozelius, N. Lubarr. DYT1 Early-Onset Isolated Dystonia. GeneReviews ${ }^{\oplus}$, Seattle (WA). https://www.ncbi.nlm.nih.gov/books/NBK1492/ (1999 updated 2016).

[10] R. Bhidayarisi, J.C. Jen, R.W. Baloh, Three brothers with a very-late-onset writers's cramp, Mov. Disord. 20 (2005) $1375-1377$.

Cécile Aerts, Alain Destée, Luc Defebvre, Alexandre Kreisler* Service de Neurologie et Pathologie du Mouvement, CHU Lille, F-59000 Lille, France E-mail address: alexandre.kreisler@chru-lille.fr

François Cassim Service de Neurophysiologie Clinique, CHU Lille, F-59000 Lille, France

Isabelle Strubi-Vuillaume, Bernard Sablonnière Centre de Biologie Pathologie, Unité de neurobiologie, CHU Lille, F-59000 Lille, France

Gwenaëlle Collod-Béroud

INSERM, GMGF UMR_S 910, Aix-Marseille Université, F-13385 Marseille, France 